\title{
Eseiści kondycji żydowskiej - po Zagładzie: Maurice Blanchot i Bogdan Dawid ${ }^{1}$ Wojdowski
}

Écrire (... ) est la violence la plus grande, car elle transgresse la Loi, toute loi et sa propre loi.

[Blanchot 1971: VIII]

To, o czym mówię, nie mija! (... ) Mówię o zamknięciu się w sobie. O lęku, który kaleczy samo dno duszy. O lęku, który kaleczy jaźn. To, do czego żaden pedagog nie sięgnie. To, czego żaden lekarz nie umie leczyć.

[Wojdowski 1987: 156]

Spróbuję przyjrzeć się porównawczo dwóm esejom: Maurice’a Blanchota pod tytułem Niezniszczalne. Być Żydem [1969; polski przekład Wandy Błońskiej - 1996] oraz Bogdana Dawida Wojdowskiego Judaizm jako los [1993]. Obydwa są esejami o późnej kondycji żydowskiej, pozagładowej. Refleksja o Wojdowskim wiele zawdzięcza monografistce jego twórczości, Alinie Molisak, której książka Judaizm jako los. Rzecz o Bogdanie Wojdowskim [2004] potwierdza rangę eseju autora Wakacji Hioba w całej jego twórczości. Osoba, która w Polsce, poza Marią Iwaszkiewicz-Wojdowską, zna go najlepiej, wybiera jako tytul swej książki mono-

1 Dawid to pierwotne imię Wojdowskiego. Takie imię nosi także główny bohater arcydzielnego Chleba rzuconego umarlym, którego postać czerpie z materii autobiograficznej. Na ten temat pisała Alina Molisak w szkicu Bogdan Dawid [1998: 10]: „Wojdowski to prawdziwe nazwisko, imię Bogdan zachował z czasów, gdy posługiwał się dokumentami Bogdana Kamińskiego, urodzonego wedle fałszywej metryki - we Włodzimierzu Wołyńskim. Po wojnie rzadko - w prywatnej korespondencji - pisarz posługiwał się prawdziwym imieniem Dawid, w ostatnich latach życia za własne uznawał oba imiona”.

2 „Pisanie to przemoc największa, ponieważ przekracza ona Prawo, wszelkie prawo i swoje własne prawo" - przeł. K.K.K. 
graficznej ten właśnie esej-testament. To gest, którego semantyka daje do myślenia.

\section{Nieostre, niezniszczalne}

Eseje Blanchota i Wojdowskiego są symptomatyczne i graniczne, pokazują kondycję żydowską po Zagładzie, niczym już nie osłoniętą, niemożność odmowy bycia Żydem (Blanchot) i bezbronność osoby, za którą nie stoi już żadna wspólnota. Bardzo wyraźnie pisze o tym Wojdowski (i nie tylko pisze; wszystkie jego usiłowania w ostatniej fazie życia, przed podjęciem decyzji o samobójstwie ${ }^{3}$ przede wszystkim inicjatywa „Masady” - stowarzyszenia i czasopisma, a także List otwarty do pisarzy pokolenia Shoah ${ }^{5}$ świadczą o próbie, niestety nieudanej, odbudowywania takiej wspólnoty):

Ocalony Żyd wbrew pozorom odnajduje siebie na pozycji dalej posuniętego wyobcowania niż kiedykolwiek w historii. O ile przedtem chroniła go grupa - gmina wyznaniowa, stan zawodowy, wspólnota chasydzka - i razem z nimi podlegał atakom, obecnie wyabstrahowany stał się celem agresji i jako jednostka uosabia wysoce niewygodnego świadka wartości unicestwionych, obciążających po czasie winnych opresji. Inaczej mówiąc: muszę zostać poddany karze symbolicznej i jako Żyd, i jako ocalony, ponieważ tylko na jednostce skupić się może wysublimowana nienawiść, nienawiść w stanie czy-

3 Data wyboru śmierci jest nieprzypadkowa - kończy życie Żyda polskiego, którego okrutnym losem było ocaleć. 19 IV 1994 roku to rocznica wybuchu powstania kwietniowego, powstania w getcie warszawskim, w roku 1943, zatem rocznica zagłady wspólnoty, całości, oparcia i początek końca diaspory. Na ten temat pisała Helena Zaworska w tekście Pozorne ocalenie [1997].

Myślę o Fundacji Kulturalnej Masada i jedynym numerze czasopisma „Masada”, datowanym na jesień 1991.

5 Pisownia „Shoah”, którą stosuje Wojdowski, jest charakterystyczna dla wczesnej fazy posługiwania się synonimami pojęcia Zagłady w polszczyźnie, gdy odwoływano się do wariantów zangielszczonych (Shoah, Holocaust). Dziś stosuje się konsekwentnie zapisy, w których rozpoznawalny jest rdzeń języków oryginalnych (Holokaust - greki; Szoa - hebrajskiego). Stąd w moim tekście pozostawiam bez zmian cytaty z Wojdowskiego, a sama piszę zgodnie z nowszą, bardziej czytelną i wiarygodną, tendencją. 
stym, która dawniej ukryta była w gąszczu przypadkowych powikłań i socjalnych sytuacji. Ten abstrakt nienawiści daje pojęcie o sile obcości, która działa w kategoriach fatum; dopiero kiedy jednostkę po usunięciu środowiska - w gigantycznym i monstrualnym eksperymencie - poddano presji antysemityzmu, judaizm w kulturze zaczyna być postrzegany jako los. [Wojdowski 1993: 61, wyróż. - K.K.K.]

I dalej - zmieniając trzecią, pozornie neutralną osobę pierwszego akapitu eseju, na osobę pierwszą - Hiobową ${ }^{6}$ :

Stając nieosłonięty na progu ontologii, nie mam już za sobą wspólnoty, do której tradycja nakazuje mi się przyznać, ani nie mam za sobą wspólnoty, która mnie przyjmie: jestem sam, więzi uległy zerwaniu, powinności wobec celu i wartości życia unieważnione i nie chronią mnie pozory, ponieważ przekroczony został próg bytu. Nie ma takiej istoty na świecie mogącej powiedzieć jednostce, jak być Żydem - jak jeszcze być Żydem. Od tego punktu każdy bywa Żydem, czyli „oskarżonym" o żydostwo, a judaizm staje się losem tych, którzy mogą być z dowolnych powodów ogarnięci judeofobią. [Wojdowski 1993: 63, wyróż. - K.K.K.]

Żyd, jak Hiob w Księdze Hioba, jest inwektywą, właściwie niewyobrażalną, a jednak rzeczywistą:

Skoro po upływie wielu generacji Żyd postrzegany jest przez zaprzeczenie, jako negacja pojęcia człowieczeństwa, a samo jego istnienie ukazywane w aurze diabolizmu, słowo oznaczające znienawidzoną (ocaloną) jednostkę używane jest nadal jako hańbiąca inwektywa. [Wojdowski 1993: 64]

6 Wojdowski jest mistrzem znaczących tytułów: obok Chleba rzuconego umartym [1971] warto wymienić ciemne i oksymoroniczne w samym zestawieniu słów Wakacje Hioba [1962]. W kontekście tego tytułu Alina Molisak cytuje we własnym tłumaczeniu słowa Jeana Améry'ego z Jenseits von Schuld und Sühne [Poza wina $i$ kara, 1966]: „Być Żydem to dla mnie ( ... ) być umarlym na urlopie, zamordowanym, który tylko przez przypadek nie jest tam, gdzie naprawdę przynależy” [Molisak 2004: 45, przyp. 1]. 
Wojdowski odpowiada na tę inwektywę, streszczającą w sobie sedno antysemityzmu:

Jako Żyd - nie akceptacji żądam, lecz wolności i to mnie łączy z każdą dowolną jednostką. Myśl, że mogą mnie akceptować ludzie godni wzgardy, wywołuje we mnie wzgardę do samego siebie. [...] Wolność bowiem nie na tym polega, że inni mają prawo mnie określić, ale że ja mam prawo określać sam siebie. [...] Celem antysemity nie jest cios w zęby, ale wymuszenie na mnie wstrząsu niezgody na siebie; nie obchodzi go, czy wyznaję wiarę mojej wspólnoty, czy wątpię i w zwątpieniu osiągam stan agnostycyzmu, czy przyjmuję chrzest, a z nim „lepszą” wiarę; osiąga triumf, kiedy uznam swoją niższość i wtrącony zostanę w kłopotliwy konflikt z własnym „ja”. Nie pokory przed absolutem ode mnie żąda, ale uznania jego samego za absolut. [Wojdowski 1993: 66]

Wojdowski polemizuje - moim zdaniem bardzo przekonująco z Jean-Paul Sartre'em, jako autorem Rozważań o kwestii żydowskiej [ [Réflexions sur la question juive, Sartre 1946], pisząc: „Definicja Sartre’a, że Żydem jest ten, którego inni za takiego uważają, nie zadowala mnie, ponieważ związana jest wyraźnie z prawem czasów pogardy i tylko w ich granicach zachowuje moc wiążącą” [Wojdowski 1993: 71]. Zestawienie tych opinii, francuskiego filozofa i ocalałego z Zagłady Żyda, pokazuje, że kwestię żydowską można rozważać, da się ją rozważać (nawet po Szoa!), zaś poeksterminacyjna kondycja żydowska nie jest sprawą wyboru. Jest kondycją tego, kto ośmielił się ocaleć. Z gorzką ironią zauważa Wojdowski:

Zastanawiające, od epoki shoah zaczęto Żydowi zarzucać arogancję: dawniej był niewierny, chciwy, śmieszny, brudny i tchórzliwy, gromadził w sobie cechy niższości, ale skoro tragizm jego losu przerósł wyobraźnię, musiano przypisać mu

7 Pierwodruk polskiego przekładu: wrześniowy/październikowy numer „Twórczości” z 1956 roku. 
cechę, która stawia go na koturnie, jak gdyby cudze zakłopotanie potrząsnęło jego obrazem i na plan pierwszy wysunęły się cechy wyższości. Kogo okryła arogancka maska? Szkielet ominięty przez śmierć głodową i Cyklon. Czy jednostka ocalona na dnie poniżenia nie ma prawa do nieufności? Do dystansu? Nie ma prawa do wyobcowania? [Wojdowski 1993: 68-69]

\section{Tytuły, osoby}

Tytuły obydwu analizowanych tu esejów wskazują na nieodwracalność.

Judaizm jako los - judaizm sensu largo, pojmowany jako kondycja żydowska po Zagładzie, kondycja tej konkretnej osoby, która przeżyła fizycznie, ale nie może o sobie mówić „ocalony/a”. Trwa to wiele lat; powstają niezwykłe, posttraumatyczne dzieła - niebywale wiarygodny obraz warszawskiego getta, gorzkie opowiadania. Opisywanie pozwala po raz kolejny odroczyć eksterminacyjny wyrok śmierci. Los jednak, kategoria z tragedii greckiej, niekompatybilna $z$ najszerzej nawet rozumianym judaizmem, doprowadza do egzekucji nosicieli winy nawet najbardziej niezawinionej. Wszystkie samobójstwa ofiar Zagłady, które - wbrew logice tejże Zagłady - przeżyły, potwierdzają nieodraczalność losu: wiele lat po czasach Endlösung zabijają się Jean Améry, Paul Celan, Primo Levi i Bogdan Wojdowski.

Sławomir Buryła cytuje - znaczący w kontekście prowadzonych tu rozważań - fragment Mezaliansu Violi Wein: „Zbudować teraźniejszość? (...) Cóż to za pojęcie, trzeba ten czas wykreślić z gramatyki! Nie ma czegoś takiego, nie ma życia w czasie teraźniejszym” [Buryła 2016: 249]. I autor tomu Wokół Zagłady następująco przytoczone słowa komentuje:

8 Nie wynikało to bynajmniej z „nadwrażliwości Wojdowskiego, który wkrótce zakończył swe życie samobójstwem" [Szczepan-Wojnarska 2011: 219], lecz właśnie z jego odporności, z walki, którą toczył o żywą pamięć Zagłady („być Żydem” według Wojdowskiego to „pamiętać, że się jest Żydem”, pisze ta sama autorka [Szczepan-Wojnarska 2011: 214] - lektura Wojdowskiego upewnia nas, że zapomnienie tożsamości żydowskiej po Zagładzie jest rzeczą niemożliwą). 
Powstaje zadziwiająca sytuacja, w której ceną za ocalenie jest egzystencja pomiędzy fałszywym istnieniem a autentycznym losem. Bogdan Wojdowski stan ten definiuje następująco: „Ale jak tu nie wspominać, kiedy - tak naprawdę, tylko przeszłość istnieje" [Pascha, z tomu Krzywe drogi - przyp. K.K.K.].Jedynie ona jest czymś doniosłym, czymś, co dla ofiary ma znaczenie i wartość. Ukryty paradoks takiego widzenia uchwycił Jan Błoński, komentując znany utwór Wojdowskiego pt. Ścieżka: „Prawdziwa jest tylko przeszłość, ale prawda przeszłości jest koszmarem, triumfem śmierci i zła ...”. Tak właśnie - koszmarem i triumfem śmierci. [Buryła 2016: 24]

Najwięksi, którzy o Zagładzie pisali, próbowali odnaleźć formę dostatecznie pojemną - w eseju, opowieści biograficznej, opowiadaniu, powieści, wierszu. Te formy albo się rozpadały, albo naruszały wiarygodność (bo jeszcze przez chwilę po Zagładzie wierzono w prawdopodobieństwo, mimesis itd.). Może najmniej rozpadał się esej, jego amorficzność okazywała się jedynie nadwątlać kategorię wiarygodności, a nie całkowicie podawać ją w wątpliwość.

Esej i los, dzięki nieprzewidywalności, ukształtowały osobę po traumie, pozwoliły jej ukazać Zagładę jako doświadczenie głęboko intymne i jednostkowe (w opozycji do Zagłady rozumianej jako własność pamięci społecznej, zbiorowości - postrzeganej wówczas jako suma faktów, naskórkowo [Szczepan-Wojnarska 2011: 213])99. Trafnie zatem - w tym punkcie - diagnozuje Szczepan-Wojnarska:

Najistotniejszym konstytutywnym czynnikiem żydostwa dla Wojdowskiego - w moim rozumieniu - jest nie miejsce, język, kultura czy religijność, ale doświadczenie Zagłady z wszelkimi jego konsekwencjami - zarówno społeczno-historycznymi, religijnymi, jak i osobistymi. [Szczepan-Wojnarska 2011:, 213, wyróż. - K.K.K.]

9 Autorka powołuje się na ustalenia Barbary Engelking z książki Zagłada i pamięć. Doświadczenia Holocaustu i jego konsekwencje opisane na podstawie relacji autobiograficznych [2001]. 
Zamieniłabym określenie „doświadczenie Zagłady” na formułę własną eseisty-samobójcy: „judaizm jako los”. Doświadczenie jest tym, co da się okiełznać, przepracować, opisać - wszystkiego tego próbował Wojdowski po eksterminacji Żydów i likwidacji warszawskiego getta, pisząc, wiele lat pisząc. Jeszcze przed powstaniem czasopisma „Masada”, które Alina Molisak nazywa „ostatnim bastionem" [Molisak 2004: 311], ostatnią próbą, by jednak obronić swoje prawo do życia, swoją rację życia, w opowiadaniu Stary doktor z tomu Krzywe drogi $[1987]^{10}$ - Wojdowski sygnalizował, że przegrywa tę walkę o własne życie: „Życia żałuje ten, któremu lekko" [Wojdowski 1987: 134]. I dalej (to słowa Rabina, skierowane do Starego Doktora): „Taki już ten świat... Rozum bez Rozumienia, Siła bez Miłości, Wieczność bez Blasku, Królestwo bez Korony i Życie bez Ozdoby”[Wojdowski 1987: 145]. I jeszcze dalej: „Każdy przecież może znaleźć te pięć minut, żeby umrzeć czytałem gdzieś” [Wojdowski 1987: 153].

Niezniszczalne. Być Żydem - zaglądam do oryginału. Tekst Blanchota, opublikowany po polsku w monograficznym numerze „Literatury na Świecie” [Blanchot 1996], poświęconym autorowi Tomasza Mrocznego, nie jest tekstem pomyślanym autonomicznie, lecz podrozdziałem książki L’Entretien infini [1969]. Tytuł oryginału brzmi: Être juif, czyli „być Żydem”. To bardzo intrygujące: nie wydaje mi się możliwe, by tak doświadczona, wybitna tłumaczka z francuskiego jak Wanda Błońska mogła się pomylić. I rzeczywiście - tytuł polski okazuje się być kontaminacją. Książka Blanchota jest podzielona na trzy duże partie: pierwszą, zatytułowaną La parole plurielle („słowo wielokrotne”); drugą, po tytułem L'experience-limite („doświadczenie-granica” / „doświadczenie graniczne”); i trzecią: L'absence de livre („nieobecność księgi/nieobecność książki”). Esej-wyimek, którym się tu zajmuję, znajduje się w części dotyczącej doświadczenia granicznego - w rozdziale piątym, zatytułowanym L'Indestructible (Niezniszczalne), składającym się z dwu podrozdziałów: Être juifi L'espèce humaine. Zatem polski tytuł to swego rodzaju autorska, zresztą bardzo celna, bo przybliżająca szerszy kontekst, propozycja twórczyni przekładu: 
kontaminacja tytułu rozdziału i podrozdziału. Gest tłumaczki czyni ten tekst tekstem osobnym, więcej niż rozdziałem (czy podrozdziałem) w książce; tytuł rozdziału i podrozdziału - spojone wystarczająco wyraźnie precyzują temat i czynią go formułą, sentencją (także w znaczeniu Kafkowskim: treścią wyroku). Warto jednak zdać sobie sprawę, że taki wariant: Niezniszczalne. Być Żydem istnieje (tylko) po polsku. Czytelnik oryginału musiałby być interpretatorem, by tę formulę wyjąć, niejako kontaminacyjnie wytworzyć. Dobrze zatem, że uczyniła to tłumaczka.

Zastanawiające jest jeszcze coś innego. Dlaczego ten właśnie fragment wyjęto i „uczyniono” autonomicznym? Czy gest tłumaczki-jako-autorki można wyjaśnić funkcjonowaniem tego fragmentu w polskiej recepcji jako osobnego eseju?

W literaturze przedmiotu wielokrotnie wskazywano na usytuowanie eseju, jako quasi-gatunku czy nie-gatunku, pomiędzy pokusami fragmentu (romantyzm) i aforyzmu (np. Cioran). Czynił to, na przykład, Walter Hilsbecher, w swym Eseju o eseju. Ekspansja europejskiego eseju to wiek xx, ale tradycje tej formy sięgają dzieł Michela de Montaigne’a we Francji i Francisa Bacona w Anglii, czyli XVI i XVII wieku, a nawet starożytności (zgodnie $\mathrm{z}$ regułą, iż nazwa jest późna, a zjawisko - wczesne, dawne). Jako szczególnie prekursorskie dzieło czytane są tu Rozmyślania (do siebie samego) Marka Aureliusza.

Zatem to, co nie jest pierwotnie pomyślane jako esej, może się nim, po prostu, okazać? Odpowiedź brzmi - tak, zwłaszcza we Francji. Najstarsza europejska szkoła pisania eseju, tradycja sporu prowadzonego precyzyjnie z samym sobą, uwiarygadnia takie zdarzenie [Loba 1994]. Więcej: gdy traktować esej jako pewien styl myślenia i pisania, a nie wykrystalizowany gatunek, gdy myśleć o kimś jako o eseiście (a o Blanchocie ${ }^{11}$ na pewno tak można!), niezależnie od tego, czy pisze obszerną rozprawę na jeden temat, czy niewielki błyskotliwy szkic, na pewno - tak. Eseista to pewna kondycja (jak Żyd, cyklista, wegetarianin) - kondycja mniejszościowa.

Blanchot nie pisze jako doświadczony, jako ten, który ośmielił się ocaleć, pisze zatem bez wyraźnej cezury Szoa. Nie ma u niego 
eskalacji po-zagładowej, która konstruuje wywody Wojdowskiego (właśnie ocalałego wbrew regule eksterminacyjnej), jest za to uniwersalna i permanentna „kondycja negatywna”, jak sam ją nazywa:

Żyd to niepewność i nieszczęście. Należy to wyraźnie powiedzieć, nawet jeśli owo twierdzenie w swej niedyskretnej prostocie jest samo w sobie nieszczęśliwe. Zawsze, w każdych czasach, Żyd jest oskarżany i uciskany. Był i jest uciskany we wszystkich społeczeństwach. Wszystkie społeczeństwa, a zwłaszcza chrześcijańskie, miały swojego Żyda, ucisk łączył je przeciwko niemu. Rzec by można - zapożyczając określenie od Franza Rosenzweiga - że w historii funkcjonuje ruch, który z każdego Żyda czyni Żyda każdego człowieka, co znaczy, że każdy człowiek, jakikolwiek by nie był, ma szczególny stosunek do odpowiedzialności, nie do końca jeszcze wyjaśniony, z tym „Bliźnim”, jakim jest Żyd. Clara Malraux mówi: „Być Żydem znaczy, że nic nie jest ci dane”. A Heine: „Judaizm? Niech mi pan o tym nie mówi, panie doktorze, nie życzę tego nawet najgorszemu wrogowi. Obelgi i wstyd, oto wszystko, co przynosi: to nie jest religia, to nieszczęście”. A zatem [...] być Żydem oznaczałoby głównie kondycję negatywną; być Żydem oznaczałoby od samego początku zostać pozbawionym najważniejszych możliwości życia i to nie abstrakcyjnie, lecz jak najbardziej realnie. [Blanchot 1996: 59-60]

Blanchot widzi - dalej - kondycję żydowską jako kondycję exodusu, „wymogu rozstania, potwierdzenia prawdy nomadów” [Blanchot 1996: 62]. Żydzi stają się narodem poprzez odwołanie do ruchu, to „naród bez ziemi, naród związany słowem” [Blanchot 1996: 62], związany poprzez rozproszenie (podobnie Wojdowski widział w zagładzie diaspory kres historii europejskich Żydów). Kondycja exodusu wiąże się z odmową osiadłości, z odmową zamieszkiwania, co tworzy zasadniczą odmienność wobec europejskiego sposobu budowania tożsamości:

Samotność Izraela, samotność kapłańską, rytualną, a także społeczną zrodziła nie tylko namiętność jego sąsiadów, ale 
i ten szczególny stosunek do samego siebie, który lokuje w najbliższym sąsiedztwie krańcową dal, nieskończony dystans, inną obecność. [ ... ] Jako Izraelita znajduje się w Królestwie. Jako Żyd jest na Wygnaniu, jakby przeznaczony do tego, by z Wygnania uczynić Królestwo. „Jakże - mówi André Neher - można być równocześnie na Wygnaniu i w Królestwie, zarazem wędrowcem i człowiekiem osiadłym? Właśnie ta sprzeczność czyni z człowieka pochodzenia żydowskiego Żyda”. [Blanchot 1996: 63-64, wyróż. - K.K.K.]

Blanchot wie, że naród, który wynalazł słowo jako możliwość przekroczenia przepaści oddzielającej człowieka od Boga („Kto widzi Boga, temu grozi śmierć” [Blanchot 1996: 67]), wyraża siebie poprzez słowa sobie podobne. Pisze eseista: „Exodus i wygnanie wyrażają to samo odniesienie do Zewnętrzności, jakie kryje też słowo egzystencja" [Blanchot 1996: 65]. I dalej:

W tym sensie słowo jest ziemią obiecaną, gdzie wygnanie zamienia się w zadomowienie, bo nie chodzi o to, by być u siebie, ale zawsze na Zewnątrz i w ruchu, w którym Obcy może się wyzwolić, nie zapierając się siebie. Mówić znaczy tyle, co szukać źródła sensu w przedrostku, za którego pośrednictwem słowa exil (zewnętrzność), exode, existence (istnienie, egzystencja), extériorité (zewnętrzność), étrangeté (obcość, dziwność), wyrażają rozmaite doświadczenia, w przedrostku, który źródeł wszystkich „pozytywnych” wartości upatruje w oddaleniu i rozdzieleniu. [Blanchot 1996: 66]

Passusy domykające rozważania Blanchota, tę próbę wyjętą spośród toku wywodów, są nadzwyczaj (w obu sensach tego słowa) konkluzywne, i - co najciekawsze w kontekście porównawczym mogłyby stanowić punkt wyjścia do lektury szkicu Wojdowskiego Judaizm jako los. Blanchot pisze:

Żydzi nie różnią się od innych w sposób, w jaki próbuje nas o tym przekonać rasizm, są jednak nosicielami świadectwa stosunku do różnicy, którą, jak mówi Lévinas, objawia nam 
ludzka twarz (tym, co w twarzy wykracza poza widzialność) i przekazuje nam odpowiedzialność; nie są obcy, lecz przypominają o wymogach obcości; nie są oddzieleni niepojętą karą, lecz jako czyste oddzielenie i czysta zależność ukazują to, co w stosunku człowieka do człowieka wykracza poza ludzką władzę, która jednak może wszystko. W tym sensie antysemityzm nie jest przypadkiem: uosabia odrazę, jaką wywołuje Bliźni, zakłopotanie wobec tego, co dalekie i inne, potrzebę zabicia Innego, czyli poddanie wszechmocy śmierci tego, czego nie można już odmierzyć w pojęciach władzy. [...] Zanegowanie to jest tak dalece absolutne, że nieustannie potwierdza ono związek z nieskończonością, jaki implikuje bycie Żydem, a którego zniszczyć nie może żadna forma władzy, ponieważ jej nie spotyka (można zabić człowieka, który jest obecny, ale nie można zniszczyć obecności pustej i zawsze nieobecnej, a tylko ją usunąć). Dlatego właśnie antysemityzm, uwikłany w spór z nieskończonością, zmienia się w bezgraniczny ruch odrzucenia. Doprawdy, wykluczenie Żydów nie wystarcza; nie dosyć zgładzić ich: trzeba by ich także usunąć z historii, wyrzucić z książek, z których do nas przemawiają, wymazać wreszcie ich obecność sprzed i po wszystkich książkach, wydrapać zapisane słowo, którym z największego oddalenia, gdzie brak już wszelkich horyzontów, człowiek zwrócił się do innego człowieka, mówiąc po prostu: zlikwidować „bliźniego”. [Blanchot 1996: 67-68, wyróż. Autora]

\section{Bez miejsca, bez poetyki}

Jeśli żyje się inercyjnie, rozpacznie - jak Wojdowski - „między gettem a Masadą", to żyje się w miejscu zaprzeczonym, w nie-miejscu. Gdy ostatnim tekstem, który się za życia publikuje, jest esej pod bezradnym, hamartycznym tytułem Judaizm jako los, diagnoza i oskarżenie jednocześnie, esej, który zajmuje niecałe siedemnaście stron $w$ druku, a powstawał przez ponad rok (1o lutego 1990 - 24 lutego 1991, nieco później niż List otwarty do pisarzy pokolenia Shoah - datowany na 4 listopada 1989 - ostatnie przywołanie współtowarzyszy, współbraci własnego losu, to znaczy, że 
wszystko, co mogło być zmyśleniem, osłoną fikcji, przestaje być istotne dla piszącego. Przestaje znaczyć: gatunek, fabuła, metafora, szerzej - poetyka.

List otwarty jest krzykiem, nawoływaniem, wypełnia go sugestywna i żarliwa argumentacja (między innymi w funkcji polemiki z ks. Józefem Tischnerem i jego koncepcją Żydów jako „niewolników Boga” w opozycji do katolików - „dzieci Bożych”):

Shoah to nie jest zwykły temat literacki, to żywy ból, troska i pamięć o bolesnym doświadczeniu, to dramat zhańbionego człowieczeństwa o uniwersalnym wymiarze, to pytanie o problematyczność istnienia człowieka na Ziemi, i nie wątpię, że to pojmują wszyscy piszący ostatnich pokoleń - od dziecka żydowskiego, które zaraz po zakończeniu wojny niewprawną ręką kreśliło relację o swoim ocaleniu, aż do dojrzałego pisarza z namysłem profesjonalisty utrwalającego obraz człowieka w obliczu zagłady mesjańskiej. [Między gettem ... 1998: 7]

Posługuje się Wojdowski, przemawiającym do wyobraźni, porównaniem choroby w stadium epidemii i w stanie endemicznym:

[...] każdy lekarz wam powie, że zakaźna choroba przybiera dwojaki kształt: epidemiczny i endemiczny. W Neapolu dawniej wybuchały nagłe epidemie cholery, z czasem zanikły, to były zarazy pochłaniające dziesiątki tysięcy ofiar [...]. Każdy lekarz wie, że w Neapolu do dziś cholera trwa w utajeniu, $\mathrm{w}$ stanie endemicznym. Podobnie jest $\mathrm{z}$ antysemityzmem - za nami wielka epidemia, która ogarnęła całą Europę i pochłonęła wiele milionów żydowskich istnień, ale co jakiś czas obserwujemy konwulsyjne nawroty zarazy, bo obecnie antysemityzm trwa w stanie endemicznym. [Między gettem ... 1998: 8]

Esej pozwala się - po raz ostatni - zmierzyć z samym sobą, zobaczyć siebie nieocalonego. Zobaczyć też inaczej niż w diariuszu, mniej radykalnie, a bardziej dyskursywnie.

We fragmentach dzienników Wojdowskiego opublikowanych w „Midraszu” można bowiem przeczytać frazy skargi bezwzględ- 
nej, ostatecznej (na które nie byłoby miejsca w eseju): „Umarlem. Dawno umarłem i nikt mi nie wierzy" (zapisek z 14 sierpnia 1984); „Życie nie było na moją miarę” (14 marca 1985); „Przeżyłem i nie przeżyłem. Wielki mój grzech. Ale go nie wybrałem. Są grzechy, na które Bóg nas sam skazuje, które sam na nas strąca" (20 kwietnia 1985); „Mój fałszywy los zaczął się w roku 1942. Mogłem wziąć ojca za rękę i pójść za nim do Treblinki. Taka była konieczność" (2o kwietnia 1985).

\section{Punkty wspólne}

Eseiści kondycji żydowskiej po Zagładzie - w wielu miejscach - się spotykają: w próbie definiowania judaizmu traktowanego kulturowo $^{12}$ (nie: wyznaniowo czy narodowo), w diagnozie kondycji negatywnej, którą warunkują tysiące lat eksterminowanej w Xx wieku diaspory i którą jednocześnie usiłuje wymusić na jednostce nowoczesny antysemityzm (to, co Wojdowski nazywa niedobrowolną „niezgodą na samego siebie”), w nazywaniu wolności, w zderzeniu kondycji ludzkiej (uniwersalnej) z kondycją szczególną, żydowską (zabitej wspólnoty), która okazuje się najbardziej radykalnym wyrazem kategorii bliźniego.

Być może przeczytać te dwa eseje obok siebie znaczy także przeczytać je wobec siebie i wobec granicznej potworności $\mathrm{xx}$ stulecia. I być może dlatego w środkowoeuropejskim państwie początku XXI wieku pali się kukłę Żyda z powodu lęku przed muzułmańskimi uchodźcami. Żyd - in effigie - to wciąż, pomimo Zagłady, najbardziej uniwersalny symbol obcości, przekraczający wszelkie granice absurdu zbiorowego imaginarium.

\section{Bibliografia}

Blanchot Maurice (1971), L'Entretien infini, Gallimard, Paris [Francja]. Blanchot Maurice (1996), Niezniszczalne. Być Źydem, przel. Wanda Błońska, „Literatura na Świecie”, nr 10, s. 59-68.

12 Pisze Alina Molisak w „Midraszu” [1997: 11]: „traktował judaizm nie jako religię, ale jako cywilizację, pewien rodzaj przekazu kulturowego formującego odrębny ogląd świata”. 
Blanchot Maurice (2009), Tomasz Mroczny. Szaleństwo dnia, przeł. Anna Wasilewska, Andrzej Sosnowski. Biuro Literackie, Wrocław.

Buryła Sławomir (2016), Wokół Zagłady. Szkice o literaturze Holokaustu, Universitas, Kraków.

Engelking Barbara (2001), Zagłada i pamięć. Doświadczenie Holocaustu i jego konsekwencje opisane na podstawie relacji autobiograficznych, IFiS PAN, Warszawa.

Girard Réné (1992), Dawna droga, którą kroczyli ludzie niegodziwi, przeł. Mirosława Goszczyńska, Spacja, Warszawa.

Hilsbecher Walter (1972), Esej o eseju, w tegoż: Tragizm, absurd i paradoks. Eseje, wstęp Stefan Lichański, Państwowy Instytut Wydawniczy, Warszawa.

Loba Mirosław (1994), Francuska szkoła pisania eseju, „Polonistyka” nr 2, s. 91-95.

Między gettem a Masada (1998), „Midrasz”, kwiecień [numer tematyczny, poświęcony Bogdanowi Wojdowskiemu].

Marek Aureliusz (2011), Rozmyślania (do samego siebie), przeł. z języka greckiego, wstęp i komentarz Krzysztof Łapiński. Wydawnictwo Czarna Owca, Warszawa.

Molisak Alina (2004), Judaizm jako los. Rzecz o Bogdanie Wojdowskim, Wydawnictwo Cyklady, Warszawa.

Sartre Jean-Paul (1992), Rozważania o kwestii żydowskiej, z francuskiego przeł. i przedmowę napisał Jerzy Lisowski, Futura Press, Łódź.

Szczepan-Wojnarska Anna M. (2011), Judaizm jako los Żyda polskiego pochodzenia - Bogdana Wojdowskiego, w: Literatura polsko-żydowska. Studia i szkice, pod red. Eugenii Prokop-Janiec i Sławomira J. Żurka, Księgarnia Akademicka, Kraków, s. 211-220.

Wein Viola (1996), Mezalians. Olsztyn.

Wojdowski Bogdan (1987), Stary doktor, w: tegoż, Krzywe drogi, Państwowy Instytut Wydawniczy, Warszawa, s. 112-173.

Wojdowski Bogdan (1991), List otwarty do pisarzy pokolenia Shoah, „Masada”, jesień, s. 7-17.

Wojdowski Bogdan (1993), Judaizm jako los, „Puls”, nr 3 (majczerwiec), s. 61-78.

Wojdowski Bogdan (1997), Oszukuj, ale żyj! Z dzienników Bogdana Wojdowskiego,„Midrasz”.

Zaworska Helena (1997), Pozorne ocalenie, „Midrasz”, maj, s. 54-56. 
Katarzyna Kuczyńska-Koschany

Essayists of Jewish condition - after the Holocaust: Maurice Blanchot and Bogdan Dawid Wojdowski

The main object of the author's reflection is the Jewish situation after the Holocaust expressed in the genre of literary essay. The thoughts of Maurice Blanchot and Bogdan Dawid Wojdowski - both prominent essayists - are taken into consideration as an example. Whereas the French writer's reflections on the Jewish situation are part of his observations about the category of infinity, the Polish essayist's realizations are intermingled with his own tragic fate as a Jew. Blanchot and Wojdowski wrote after the Holocaust, which is an unique turning point in history for the Jews and their diaspora as well as for the Mediterranean culture.

Keywords: essay; Jewish situation; Holocaust; Wojdowski Bogdan Dawid; Blanchot Maurice.

Katarzyna Kuczyńska-Koschany (ur. 20 grudnia 1970) - prof. w Instytucie Filologii Polskiej UAM, komparatystka, eseistka, prozaik. Zajmuje ją przede wszystkim: poezja i jej interpretacja, recepcja poetów niemieckiego i francuskiego kręgu językowego w Polsce, kultura Żydów polskich i niemieckich, Zagłada Żydów w Europie, relacje intersemiotyczne w poezji i plastyce. Autorka książek: Rilke poetów polskich (2004; wyd. II - 2017), Rycerz i Śmierć. $O$ „Elegiach duinejskich” Rainera Marii Rilkego (2010; wyd. II, e-book, 2015), Interlinie w ciemności. Jednak interpretacja (2012), „Bсе nоэты жиды“. Antytotalitarne gesty poetyckie i kreacyjne wobec Zagłady oraz innych doświadczeń granicznych (2013), Skąd się bierze lekcja polskiego? Scenariusze, pomysty, konteksty (2016), tomu prozy Zielony promień (2006), współautorka podręcznika Staropolskie korzenie wspótczesności (2004). Publikowała w „Czasie Kultury”, „Literaturze na Świecie”, „Odrze”, „Poznańskich Studiach Polonistycznych”, „Przestrzeniach Teorii”, „Ruchu Literackim”, „Slavii Occinedtalis”, „Zagładzie Żydów. Studiach i Materiałach”, „Zeszytach Literackich”. Współpracuje z czasopismem „Polonistyka. Innowacje“, należy do Rady Programowej „Miasteczka Poznań“ i Rady Naukowej „Narracji o Zagładzie”. Członkini Zespołu Badań nad Literaturą Zagłady IBL PAN, Komitetu Nauk o Literaturze PAN, Otwartej Rzeczpospolitej, Komisji ds. przeciwdziałania dyskryminacji przy Rektorze uAM. Opiekunka Koła Naukowego Miłośników Kultury i Literatury Żydowskiej „Dabru emet“ (UAM). Obecnie kieruje Pracownią Badań nad Tradycją Europejską IFP UAM. 
